International

Medical Society

http://imedicalsociety.org
Vol. 9 No. 194

doi: $10.3823 / 2065$

\section{Quality of Life of Academic Dentists' Families; a Cross-Sectional Survey}

\section{Abstract}

Background and objectives: Quality of the social life of dentists has not been given much attention in literature. Further, the quality of dental academics' families has never been investigated before. The aim of this study is to assess some aspects of the quality of life among academic dentists' families and to investigate the factors that may influence their quality of life.

Methods: This study was based on an online questionnaire. The questionnaire was composed of two parts; the first part was directed to academic and non-academic dentists asking them about relevant demographic/professional data, and the second part was directed to their family members asking them about social, cultural, financial and health-related issues. Data were analyzed to obtain descriptive statistics and determine significance of association of different variables.

Findings: A total of 125 dentists (academics $=37$, non-academics $=88$ ) participated in the survey together with their family members. Most of the social aspects were satisfactorily prevailing in families of both groups, however, statistically significant differences were found in some financial aspects indicating that non-academics' families live a more well-off life style.

Conclusions: Families of academic and non-academic dentists showed comparable quality of life, however, they were affected by similar trends affecting families nowadays like long hours of internet usage, obesity, and waterpipe smoking, the latter was exclusively found in non-academic dentists' families.
Ibrahim Nourwali', Osama Abu Hammad², Najla Dar Odeh²

1 Assistant Professor, College of Dentistry, Taibah University, Al Madina Al Monawara, Saudi Arabia.

2 Professor, Faculty of Dentistry, University of Jordan, Amman, Jordan and College of Dentistry, Taibah University, Al Madina Al Monawara, Saudi Arabia.

\section{Contact information:}

\section{Najla Dar Odeh.}

Address: Faculty of Dentistry, University of Jordan, Amman, Jordan, and College of Dentistry, Taibah University, Al Madina Al Monawara, Saudi Arabia.

Tel: +966592231888 .

झ najla_dar_odeh@yahoo.com

\section{Keywords}

Quality of Life; Dentists; Families; Academics. 


\section{Background}

Dentistry as a profession is stressful, [1, 2] and may lead to adverse impact on the dentists' quality of life. [3-6] Dentists are at risk of developing physical health complaints as a result of their work environment including infections, chemical and radiation injury, hearing and neuropathic problems. [7] Within the social context, a recent study showed that the majority of the study sample of dentists were dissatisfied with their personal time due to long working hours. [8] Gender and age may play a role in determining the type and frequency of complaints. For instance, female dentists seem to be more at risk to develop physical complaints and psychological distress than their male colleagues. [9] Also, with increasing age, the prevalence of mental complaints such as anxiety, sleeplessness, feeling of loneliness. [10] and musculoskeletal physical complaints [11] tend to increase.

Academic dentistry as a career can be intellectually stimulating and consistently exciting through teaching and research away from boredom and monotony. On the other hand, certain challenges can adversely affect the academic career like difficulty in obtaining research grants, limited pay and competitiveness with colleagues. [12]

Literature reported on the job satisfaction of dentists, $[13,14]$ and many studies reported on the occupational health hazards that dentists are exposed to. $[15,16]$ Quality of social life of dentists, on the other hand, was not given much attention. Further, up to our best knowledge no studies were done so far on the quality of life of dentists' families. This is in contrary to the medical profession which has gained much attention in this regards as shown by studies investigating critical issues like work- home conflict among physicians whether there is one parent, [17] or both parents working as physicians in the same family. [18]

It is important to investigate quality of life of the families of academic dentists. Life style/ family compatibility has been listed among the positive influen- ces on the quality of the academic work environment and career satisfaction among dental school faculty. [19]

While personal issues leave their impact on the professional success of academics, job satisfaction and professional success will inevitably influence family life.

The aim of this study is to assess some aspects of the quality of life of families of academic dentists and compare them to those of non-academic dentists and to investigate the factors that may influence the quality of life.

\section{Participants and Methods}

Ethical approval was obtained from Research Ethics Committee of College of Dentistry, Taibah University, in the Central Western region of Saudi Arabia, and was granted after providing copies of research proposal, consent form and questionnaire.

\section{The questionnaire}

This was a questionnaire based study. The questionnaire was composed of 2 parts; first part was directed to dentists consisting of questions on demographic/professional data of gender, age, nationality, marital status, year and country of graduation, final specialty degree and its field if applicable, experience in years, work sector (public or private), affiliation (private practice, public hospital, private hospital, academia, other), average work hours/ week, city of work and city of residence. Also if they travel between workplace and residence.

The second part was composed of questions directed to family members. These questions were about: relation to dentist, gender, age, educational level, type of residence (apartment, house/viIla), whether they own or rent the house, or if housing allowance was provided by the employer. Other questions included: occupation of the family member, data on schooling for the children, shopping, dining, fast food consumption, tobacco 
use pattern and behavior, practice of sports, health insurance, dialogue and transparency in the family, presence of investments, oral hygiene practices, use of internet and social media, reading books, number of cars owned by family, bank loans, presence of driver(s) and maid(s), and average number of sleeping hours.

A copy of the questionnaire was prepared using Google Forms TM and a link was created.

The questionnaire was designed by all co-authors and was prepared in Arabic language. It was first distributed to 10 dentists and their family members. It was then sent for the same participants after one week. Different responses were investigated with the same participant for clarity/aim, then the wording was changed when necessary until there were no differences in the responses.

\section{Participants}

The link to the questionnaire was distributed to a number of dentists' groups on the WhatsApp ${ }^{\mathrm{TM}}$ smart-phone application. There were a total of 300 dentists who were either: intern dentists, general dentists or specialist dentists. Each group received 2 subsequent reminders over two consecutive weeks to participate in the study.

The Epi Info software (Center for Disease Control and Prevention) was used for sample size determination. Population size was set to be: the total number of dentists in the city of Al Madina, Saudi Arabia. Total number of dentists was about 400 dentists, with 50\% expected frequency, 5\% confidence limit, and 1 cluster. At $80 \%$ power of study sample size was calculated to be 116 participants, and at $90 \%$ power of the study sample size was calculated to be 161 subjects.

\section{Statistical analysis}

After data collection, analysis was carried out using IBM-SPSS version 21.

Kolmogorov-Smirnoff test was used to determine normal distribution of the sample. Cross tabulation with Chi square was used to determine significance of association between variables.

\section{Results}

Out of 300 dentists in WhatsApp ${ }^{T M}$ groups who were invited to participate, a total of 133 dentists responded by completing the online questionnaire. The number of this convenient sample was further reduced to 125 after eliminating 8 responses as they did not answer a large number of questions. The response rate thus, after eliminating empty responses, was around $41.7 \%$. This produced a power of study between $80 \%$ and $90 \%$.

Forty five subjects (36\%) were family members of female dentists while 80 subjects (64\%) were family members of male dentists. Thirty seven (29.6\%) dentists were academics (17 males and 20 females) and 88 (70.4\%) were non-academics (63 males and 25 females).

Specialty degrees for non-academics were significantly different to the academics', with more doctorate degrees among academics. Table 1 shows other relevant sociodemographic characteristics of dentists who participated in the survey, and Table 2 shows the sociodemographic characteristics of their family members. (Table 1, 2)

Table 1. Relevant sociodemographic and professional data of the dentists who participated in the survey.

\begin{tabular}{|c|c|c|c|}
\hline Variable & $\begin{array}{c}\text { Academics } \\
\text { no }=37\end{array}$ & $\begin{array}{c}\text { Non- } \\
\text { academics } \\
\text { no }=88\end{array}$ & $\begin{array}{c}P \\
\text { value }\end{array}$ \\
\hline $\begin{array}{l}\text { Age (Mean } \pm \text { SD) } \\
\text { range (years) }\end{array}$ & $\begin{array}{c}(39.5 \pm 6.7) \\
27-50\end{array}$ & $\begin{array}{c}(36.8 \pm 9.0) \\
24-73\end{array}$ & 0.110 \\
\hline \multicolumn{4}{|l|}{ Nationality } \\
\hline Saudi & $7(18.9 \%)$ & $48(54.5 \%)$ & \multirow{2}{*}{0.000} \\
\hline Non-Saudis (N, \%) & $30(81.1 \%)$ & $40(45.5 \%)$ & \\
\hline $\begin{array}{l}\text { Marital status } \\
\text { Divorced, married, } \\
\text { single }\end{array}$ & $1,35,1$ & $4,74,10$ & 0.250 \\
\hline $\begin{array}{l}\text { Year of obtaining } \\
\text { bachelor's degree } \\
\text { Range (Mean } \pm \text { SD) }\end{array}$ & $\begin{array}{l}1987-2013 \\
(1998 \pm 7.4)\end{array}$ & $\begin{array}{l}1967-2015 \\
(2002 \pm 9.2)\end{array}$ & 0.012 \\
\hline
\end{tabular}




\begin{tabular}{|c|c|c|c|}
\hline Variable & $\begin{array}{c}\text { Academics } \\
\text { no }=37\end{array}$ & $\begin{array}{c}\text { Non- } \\
\text { academics } \\
\text { no }=88\end{array}$ & $\begin{array}{c}P \\
\text { value }\end{array}$ \\
\hline \multirow{4}{*}{ Academic degrees } & $\mathrm{PhD}(\mathrm{n}=24)$ & Board $(n=17)$ & \multirow{4}{*}{0.000} \\
\hline & Master $(n=8)$ & Master $(n=15)$ & \\
\hline & Board $(n=2)$ & $\operatorname{PhD}(n=9)$ & \\
\hline & $\operatorname{BDS}(n=3)$ & $\operatorname{BDS}(n=47)$ & \\
\hline
\end{tabular}

Work Experience

(Range in years)

(Mean \pm SD)

Results show that there are significantly less Saudi academics in the sample, and that academic dentists have graduated significantly earlier than non- academics (Mean=1998 and 2002 respectively). Moreover, their professional degrees vary significantly

Family members participating in the survey were: 77 (61.6\%) females and 43 (34.4\%) males while 5 (4\%) subjects did not state their gender.

Age of subjects ranged from 16 to 65 , and 12

Table 2. Sociodemographic characteristics of the dentists' families.

\begin{tabular}{|c|c|c|c|c|c|}
\hline Variable & \multicolumn{2}{|c|}{$\begin{array}{l}\text { Academic } \\
\text { dentists' } \\
\text { families }\end{array}$} & \multicolumn{2}{|c|}{$\begin{array}{c}\text { Non-academic } \\
\text { dentists' } \\
\text { families }\end{array}$} & $\begin{array}{c}\text { P } \\
\text { value }\end{array}$ \\
\hline $\begin{array}{l}\text { Age } \\
\text { (Mean } \pm \text { SD) } \\
\text { range (years) }\end{array}$ & \multicolumn{2}{|c|}{$\begin{array}{c}(35.2 \pm 12.1) \\
16-59\end{array}$} & \multicolumn{2}{|c|}{$\begin{array}{c}(34.04 \pm 12.3) \\
16-65\end{array}$} & 0.634 \\
\hline \multirow{5}{*}{$\begin{array}{l}\text { Spouses' } \\
\text { education } \\
\text { level } \\
(\mathrm{N}, \%)\end{array}$} & $\begin{array}{l}\text { High } \\
\text { school }\end{array}$ & $\begin{array}{c}1 \\
(2.8 \%)\end{array}$ & $\begin{array}{l}\text { High } \\
\text { school }\end{array}$ & $3(8.1 \%)$ & \multirow{5}{*}{0.106} \\
\hline & Diploma & 0 & Diploma & $2(5.4 \%)$ & \\
\hline & Bachelors & $\begin{array}{c}20 \\
(55.6 \%)\end{array}$ & Bachelors & $\begin{array}{c}26 \\
(70.3 \%)\end{array}$ & \\
\hline & Masters & $\begin{array}{c}10 \\
(27.8 \%)\end{array}$ & Masters & $\begin{array}{c}4 \\
(10.8 \%)\end{array}$ & \\
\hline & $\mathrm{PhD}$ & $\begin{array}{c}5 \\
(13.9 \%)\end{array}$ & $\mathrm{PhD}$ & $\begin{array}{c}2 \\
(5.4 \%)\end{array}$ & \\
\hline \multirow{7}{*}{$\begin{array}{l}\text { Participating } \\
\text { family } \\
\text { members' } \\
\text { educational } \\
\text { level }(N, \%)\end{array}$} & $\begin{array}{l}\text { Middle } \\
\text { school }\end{array}$ & 0 & Missing & $\begin{array}{c}3 \\
(3.4 \%)\end{array}$ & \multirow{7}{*}{0.145} \\
\hline & $\begin{array}{l}\text { High } \\
\text { school }\end{array}$ & $\begin{array}{c}6 \\
(16.2 \%)\end{array}$ & $\begin{array}{l}\text { Middle } \\
\text { school }\end{array}$ & $4(4.5 \%)$ & \\
\hline & Diploma & $1(2.7 \%)$ & $\begin{array}{l}\text { High } \\
\text { school }\end{array}$ & $\begin{array}{c}12 \\
(13.6 \%)\end{array}$ & \\
\hline & Bachelors & $\begin{array}{c}16 \\
(43.2 \%)\end{array}$ & Diploma & $4(5.4 \%)$ & \\
\hline & Masters & $\begin{array}{c}10 \\
(27 \%)\end{array}$ & Bachelors & $\begin{array}{c}50 \\
(56.8 \%)\end{array}$ & \\
\hline & \multirow[t]{2}{*}{$\mathrm{PhD}$} & \multirow[t]{2}{*}{$\begin{array}{c}4 \\
(10.8 \%)\end{array}$} & Masters & $\begin{array}{c}9 \\
(10.2 \%)\end{array}$ & \\
\hline & & & PhD & $\begin{array}{c}6 \\
(6.8 \%)\end{array}$ & \\
\hline \multicolumn{6}{|c|}{ Residence, work same city (N,\%) } \\
\hline Yes & \multicolumn{2}{|c|}{$27(73 \%)$} & \multirow{2}{*}{\multicolumn{2}{|c|}{$\begin{array}{c}76(86.4 \%) \\
11(12.5 \%)\end{array}$}} & \multirow{2}{*}{0.119} \\
\hline No & \multicolumn{2}{|c|}{$10(27 \%)$} & & & \\
\hline
\end{tabular}

Table 3. Social and cultural aspects of the study sample.

\begin{tabular}{|c|c|c|c|}
\hline Variable & $\begin{array}{l}\text { Academics } \\
\text { no }=37\end{array}$ & $\begin{array}{c}\text { Non- } \\
\text { academics } \\
\text { no }=88\end{array}$ & $\begin{array}{l}P \\
\text { value }\end{array}$ \\
\hline $\begin{array}{l}\text { Age (Mean } \pm \text { SD) } \\
\text { Number of children } \\
\text { in the family range }\end{array}$ & $\begin{array}{l}(2.8 \pm 1.5) \\
1-8\end{array}$ & $\begin{array}{l}(2.7 \pm 1.4) \\
1-7\end{array}$ & 0.849 \\
\hline \multicolumn{4}{|c|}{ Type of schools (N, \%) } \\
\hline Public & $4(16 \%)$ & $18(25.4 \%)$ & \multirow{2}{*}{0.253} \\
\hline Private & $21(84 \%)$ & $53(74.6 \%)$ & \\
\hline \multicolumn{4}{|l|}{ School achievement } \\
\hline Excellent & $13(44.8 \%)$ & $45(62.5 \%)$ & \multirow{3}{*}{0.417} \\
\hline Very good & $12(41.4 \%)$ & $21(29.2 \%)$ & \\
\hline Good & $4(13.8 \%)$ & $6(8.3 \%)$ & \\
\hline \multicolumn{4}{|c|}{ Do parents assist their children in study? } \\
\hline Yes & $19(67.9 \%)$ & $54(76 \%)$ & \multirow{2}{*}{0.584} \\
\hline No & $9(32.1 \%)$ & $17(23.9 \%)$ & \\
\hline \multicolumn{4}{|c|}{$\begin{array}{l}\text { Do you feel your parent's career deprives you from their } \\
\text { care? }\end{array}$} \\
\hline Yes & $19(51.4 \%)$ & $56(65.1 \%)$ & \multirow{2}{*}{0.231} \\
\hline No & $18(48.6 \%)$ & $30(34.9 \%)$ & \\
\hline \multicolumn{4}{|c|}{ Do you travel annually? } \\
\hline Yes & $26(70.3 \%)$ & $75(85.2 \%)$ & \multirow{2}{*}{0.5051} \\
\hline No & $11(29.7 \%)$ & $11(12.5 \%)$ & \\
\hline $\begin{array}{l}\text { Do all family travel } \\
\text { together? }\end{array}$ & 1 (missing) & 13 (missing) & \\
\hline Yes & $25(67.6 \%)$ & $42(47.7 \%)$ & \multirow{2}{*}{0.827} \\
\hline No & $11(29.7 \%)$ & $33(37.5 \%)$ & \\
\hline \multicolumn{4}{|c|}{ Do you dine outdoors? } \\
\hline Yes & $29(78.4 \%)$ & $77(87.5 \%)$ & \multirow{2}{*}{0.153} \\
\hline No & $8(21.6 \%)$ & $11(12.5 \%)$ & \\
\hline
\end{tabular}




\begin{tabular}{|c|c|c|c|}
\hline Variable & $\begin{array}{c}\text { Academics } \\
\text { no }=37\end{array}$ & $\begin{array}{c}\text { Non- } \\
\text { academics } \\
\text { no }=88\end{array}$ & $\begin{array}{c}P \\
\text { value }\end{array}$ \\
\hline \multicolumn{4}{|c|}{ Who dines outdoors? } \\
\hline Parents only & $3(10.7 \%)$ & $75(85.2 \%)$ & \multirow{2}{*}{0.5051} \\
\hline All family & $25(89.3 \%)$ & $6(7.7 \%)$ & \\
\hline \multicolumn{4}{|c|}{ Do you dine together regularly? } \\
\hline Yes & $29(78.4 \%)$ & $77(87.5 \%)$ & \multirow{2}{*}{0.195} \\
\hline No & $8(21.6 \%)$ & $11(12.5 \%)$ & \\
\hline $\begin{array}{l}\text { Having fast food } \\
\text { times/week? }\end{array}$ & $2.0 \pm 1.47$ & $2.4 \pm 1.54$ & \\
\hline 1-3 times/ week & 34 & 69 & \multirow{3}{*}{0.175} \\
\hline 4-5 time/ week & 1 & 13 & \\
\hline 6-7 times/week & 2 & 4 & \\
\hline Foreign languages & $2.19 \pm 0.524$ & $2.06 \pm 0.561$ & \\
\hline One language & $n=1$ & $n=11$ & \multirow{4}{*}{0.215} \\
\hline Two languages & $n=28$ & $n=59$ & \\
\hline Three languages & $\mathrm{n}=6$ & $n=16$ & \\
\hline Four languages & $n=1$ & $n=0$ & \\
\hline \multicolumn{4}{|c|}{ Family dialogue and conversation } \\
\hline Yes & $31(83.8 \%)$ & $69(79.3 \%)$ & \multirow{2}{*}{0.1684} \\
\hline No & $6(16.2 \%)$ & $18(20.7 \%)$ & \\
\hline \multicolumn{4}{|c|}{ Average internet use hours/day } \\
\hline & $4.52 \pm 2.14$ & $4.45 \pm 2.27$ & \multirow{2}{*}{0.890} \\
\hline Range & $1-10$ & $1-10$ & \\
\hline \multicolumn{4}{|c|}{ Do you read a book/month? } \\
\hline Yes & $6(17.6 \%)$ & $28(31.8 \%)$ & \multirow{2}{*}{0.008} \\
\hline No & $28(82.4 \%)$ & $6(68.2 \%)$ & \\
\hline
\end{tabular}

of social and cultural behavior of dentists' families which are comparable in both groups however, families of non-academics read significantly more books/month.

When percentages don't add up to $100 \%$, this is because of missing data (unanswered questions)

Table 4 shows the financial and economic characteristics of the study sample. Non- academics' families more significantly live in villas than academics' families, have more bank loans and have family drivers.

Table 5 shows important health indicators in the study sample. The following criteria are significantly associated with non-academics' families; waterpipe smoking, practicing sports and having depression.
Table 4. Financial and economic aspects of the study group. When numbers don't add, this is because of missing data (unanswered questions).

\begin{tabular}{c|c|c|c} 
Variable & $\begin{array}{c}\text { Academics } \\
\text { no=37 }\end{array}$ & $\begin{array}{c}\text { Non- } \\
\text { academics } \\
\text { no=88 }\end{array}$ & $\begin{array}{c}P \\
\text { value }\end{array}$ \\
\hline
\end{tabular}

Do you have currently any financial projects?

\begin{tabular}{|c|c|c|}
\hline Public & $6(16.2 \%)$ & $18(25.4 \%)$ \\
\hline Private & $29(78.4 \%)$ & $21(23.9 \%)$ \\
\hline \multicolumn{3}{|c|}{ Are you planning for future financial projects } \\
\hline Kes & $14(37.8 \%)$ & $45(62.5 \%)$ \\
\hline & 22 (59.5) & 43 (48.9\%) \\
\hline
\end{tabular}

Number of cars

\begin{tabular}{l|c|c|c|}
\hline Range & $1.6 \pm 0.8$ & $1.8 \pm 0.9$ & 0.307 \\
\hline $\begin{array}{l}\text { Type of residence } \\
\text { Apartment }\end{array}$ & $\begin{array}{c}\text { 36 (97.3\%) } \\
\text { Villa }\end{array}$ & $\begin{array}{c}62(70.5 \%) \\
\text { Bank loans }\end{array}$ & 0.001 \\
\hline Yes & $12.7 \%)$ & $26(29.5 \%)$ & \\
No & $25(67.6 \%)$ & $36(59.1 \%)$ & 0.006 \\
\hline
\end{tabular}

Buy designer's items:

\begin{tabular}{|l|c|c|c|}
\hline Yes & $12(32.4 \%)$ & $26(29.5 \%)$ & 0.633 \\
\hline No & $25(67.6 \%)$ & $60(68.2 \%)$ & \\
\hline Family driver & & & \\
\hline Yes & $5(13.5 \%)$ & $32(36.4 \%)$ & 0.028 \\
\hline No & $32(86.5 \%)$ & $55(62.5 \%)$ & \\
\hline Maids & $10(27 \%)$ & $36(40.9 \%)$ & 0.256 \\
\hline Yes & $27(73 \%)$ & $51(58.5 \%)$ & \\
\hline No & & & \\
\hline Number of maids & $1 \pm 0$ & $1.2 \pm 0.48$ & 0.185 \\
\hline Mean & & &
\end{tabular}

Table 5. Health indicators of the study sample.

\begin{tabular}{|l|c|c|c|}
\hline \multicolumn{1}{|c|}{ Variable } & $\begin{array}{c}\text { Academics } \\
\text { no=37 }\end{array}$ & $\begin{array}{c}\text { Non- } \\
\text { academics } \\
\text { no=88 }\end{array}$ & $\begin{array}{c}\text { P } \\
\text { value }\end{array}$ \\
\hline Do you smoke tobacco? & & \\
\hline $\begin{array}{l}\text { Yes } \\
\text { No }\end{array}$ & $\begin{array}{c}5(13.5 \%) \\
\text { 32(86.5\%) }\end{array}$ & $\begin{array}{l}22(25.6 \%) \\
\text { (74.4\%) }\end{array}$ & 0.215 \\
\hline Do you smoke waterpipe? & & \\
\hline Yes & $0(0 \%)$ & $15(20.3 \%)$ & 0.028 \\
\hline No & $30(100 \%)$ & $59(79.7 \%)$ & \\
\hline
\end{tabular}




\begin{tabular}{|c|c|c|c|}
\hline Variable & $\begin{array}{c}\text { Academics } \\
\text { no }=37\end{array}$ & $\begin{array}{c}\text { Non- } \\
\text { academics } \\
\text { no }=88\end{array}$ & $\begin{array}{c}\mathbf{P} \\
\text { value }\end{array}$ \\
\hline \multicolumn{4}{|c|}{ Do you Sport regularly? } \\
\hline Yes & $5(13.5 \%)$ & $9(10.3 \%)$ & \multirow{2}{*}{0.613} \\
\hline No & $32(86.5 \%)$ & $78(89.7 \%)$ & \\
\hline $\begin{array}{l}\text { Sporting occasions/ } \\
\text { week }\end{array}$ & $1.9 \pm 0.82$ & $2.6 \pm 1.5$ & 0.017 \\
\hline \multicolumn{4}{|c|}{ Subscription to fitness club } \\
\hline Yes & $17(47.2 \%)$ & $28(36.4 \%)$ & \multirow{2}{*}{0.126} \\
\hline No & $19(52.8 \%)$ & $49(63.6 \%)$ & \\
\hline \multicolumn{4}{|l|}{ Obesity in the family } \\
\hline Yes & $16(43.2 \%)$ & $34(41 \%)$ & \multirow{2}{*}{0.325} \\
\hline No & $21(56.8 \%)$ & $49(59 \%)$ & \\
\hline \multicolumn{4}{|l|}{ Sleep hours/ night } \\
\hline & $6.11 \pm 1.05$ & $6.05 \pm 1.33$ & \multirow{2}{*}{0.816} \\
\hline Range & $4.5-8.5$ & $3.5-9.5$ & \\
\hline \multicolumn{4}{|c|}{ Happy about health insurance } \\
\hline Mean rank & 69.29 & 58.37 & 0.110 \\
\hline \multicolumn{4}{|c|}{ Self-reported chronic diseases } \\
\hline Yes & $12(33.3 \%)$ & $26(29.9 \%)$ & \multirow{2}{*}{0.761} \\
\hline No & $24(66.7 \%)$ & $61(70.1 \%)$ & \\
\hline \multicolumn{4}{|c|}{ Adhere to high oral hygiene standards: } \\
\hline Mean & $22(61.1 \%)$ & $52(59.1 \%)$ & \multirow{2}{*}{0.295} \\
\hline No & $14(38.9 \%)$ & $36(40.9 \%)$ & \\
\hline \multicolumn{4}{|c|}{ Do you have depression } \\
\hline Mean rank & 49.84 & 62.75 & 0.038 \\
\hline
\end{tabular}

\section{Discussion}

This study investigated important aspects of the quality of life of academic dentists' families compared to non-academic dentists. Both groups had comparable demographics when addressing important variables like age, marital status, and years of experience in their careers. However, both groups were not matched in nationality; most of the academics group expectedly, were non-Saudi nationals and most of the non-academics were Saudis. Saudi higher education in general still relies on large numbers of non-Saudis particularly in health-related specialties. In recent years, however, the continuous efforts of government to sponsor abroad postgraduate studies through the grant of the Custodian of the two great mosques (Menhat Khadem Al Haramain in Arabic), have provided more Saudis in the academic work force. So it is expected that there will be more Saudi academics working in Saudi universities during the next decade. Also, almost half of the non-academic dentists' sample had higher degrees like Board, masters and PhD. As for the academic degrees that both groups of dentists have, there was a statistically significant difference since the group of academics expectedly had more postgraduate degrees. Another statistically significant difference was noticed between both groups in the year of obtaining the bachelor's degree; nonacademics have graduated more recently than academics mainly after the year 2000. Regarding the families of both groups, they were matched in age, education level of the spouses and of other family members. This contributes to the validity of results provided by this study.

Important social aspects were investigated in this study. Perhaps the most important of these is children; they are the center of concern in any family. Indeed, balancing family and career responsibilities was a prevalent problem and was the strongest predictor of discontent among a sample of faculty at an American school of medicine. [20] In both academic and non-academic groups children received tutoring mostly in private schools. Furthermore, children achievement in school was mostly excellent or very good. A satisfactory family atmosphere was evident as the general trend was assisting children in their study, and having meals as a family by dining outdoors, and lunching at home where the main trend was home-cooked meals and having fast foods less frequently.

From the children's perspective, the children of both groups mostly feel that their parents' dental career deprive them from care, but at the same time, almost half of the children in both groups feel that their parents are caring, and most of them believe that there is dialogue in the family. Socially and culturally both academic and non-academic 
families were similar in being bilingual and undertaking annual travels with all the family travelling together. Both groups showed a high use of internet daily of around 5 hours, while a minority of academics' and one third of non-academics' families read one book per month and the difference is significant favoring the non-academics' families. A long screen time, including internet usage has been linked to a number of adverse outcomes. Excess body weight in adolescents has been related to sedentary behaviors like screen time. [21] Screen time exceeding 3 hours has been associated with poor health, [22] low academic performance, [23] and obesity. [24] Interestingly, approximately 40\% of the study sample in both groups report obesity in the family

Some important health indicators were investigated including tobacco smoking, oral hygiene habits, and sporting. A minority smoke cigarettes in both groups. As for waterpipe smoking, a tobacco use method that has gained increased popularity in recent years, none of the academics' and approximately $20 \%$ of non-academics' families smoked waterpipe showing a statistically significant difference between both groups. Evidence suggests that water pipe smoking is gaining popularity among populations that may "resist" cigarette smoking as the former is mistakenly perceived a healthier option for tobacco use. The increased popularity has been reported among physicians, [25] and medical students. [26] The academics in a university in a neighboring country have also been reported to smoke the waterpipe at a prevalence of $13.5 \%$. [27] There are no studies published so far on the prevalence of waterpipe smoking among dentists in general. Recently, we conducted a study in Al Madina/ Saudi Arabia to investigate waterpipe tobacco smoking among dentists and found that almost $25 \%$ of them smoke the waterpipe on a regular basis (unpublished data). When considering the fact that none of the academic dentists families smoke waterpipe, one must be cautious when interpreting the results, since studies have shown that the practice of water pipe smoking is not dependent on cultural background or educational level of smokers. [28] Academics are supposed to be role models for their students as well as their families, and their health risk behaviors are also supposed to be minimal. Whether this has an influence on the practice of waterpipe smoking or not, further research may be needed. Results showed that non-academic dentists' family practice sport weekly more significantly than academic families, however, almost half of the sample in both groups reported obesity in the family, and almost one third of both groups reported the presence of chronic diseases in the family. Most of both groups have private medical care, and almost half of both groups have free medical insurance, the latter is a favorable health indicator.

High oral hygiene standards were reported by almost $60 \%$ of the sample in both groups. This was not expected as the families of dentists in general, whether academics or not, should acquire and practice good oral hygiene habits. Another interesting finding was the statistically significant difference in reporting depression between both groups with a higher depression rank among families of non-academics. This finding needs more in-depth research to explore its causes.

We did not include questions on the monthly income of the family because it is better to investigate the indicators of financial security. Financially less than half of each groups have financial projects, but a higher percentage plan to do financial projects in the future. Both groups own at least one car but more non-academics live in villas and the difference is significant. Another statistically significant difference was noticed in having a family driver, a trend which was more prevalent in non-academic families. Both of these findings do not necessarily reflect financial prosperity since significantly more non-academic families have bank loans than academic families. Although non-academics' families 
may have up to 3 maids, there was no statistically difference in having maids between both groups.

Academia is known to be associated with a limited pay, however, an advantage of academia is that it provides a predictable, steady source of income and benefits that increase over time.

In general quality of life of academic dentists and their families may vary according to geographic location and this study is no exception since our sample live in a country that is known to be one of the richest countries in the Middle East.

Academic dentistry in North America and Europe may face a different situation. It has been stated that dental education in the United States faces shortage of faculty that is reaching crisis proportions. [29] The ageing academics is one of the problems that face academic dentistry. [30] This is paralleled by increase in the number of professors starting from the year 2000 and a decrease in lecturers. [31]

\section{Conclusions}

It can be concluded that families of academic and non-academic dentists showed comparable quality of life, however, they are affected by similar trends affecting families nowadays like long hours of internet usage, obesity, and waterpipe smoking, and the latter was exclusively affecting non-academic dentists' families. More research is needed to explore some interesting findings among academic and non-academic dentists' families.

\section{Competing and conflicting interests}

Authors declare that there is no conflict of interest.

\section{References}

1. Soma, K.J., Thomson, W.M., Morgaine, K.C., and Harding, W.J.: 'A qualitative investigation of specialist orthodontists in New Zealand: part 2. Orthodontists' working lives and work-life balance', Australian orthodontic journal, 2012, 28, (2), pp. $170-$ 180.
2. Gilmour, J., Stewardson, D.A., Shugars, D.A., and Burke, F.J.: 'An assessment of career satisfaction among a group of general dental practitioners in Staffordshire', British dental journal, 2005, 198, (11), pp. 701-704, discussion 693

3. Logan, H.L., Muller, P.J., Berst, M.R., and Yeaney, D.W.: 'Contributors to dentists' job satisfaction and quality of life', The Journal of the American College of Dentists, 1997, 64, (4), pp. $39-43$

4 Puriene, A., Aleksejuniene, J., Petrauskiene, J., Balciuniene, I., and Janulyte, V.: 'Occupational hazards of dental profession to psychological wellbeing', Stomatologija / issued by public institution "Odontologijos studija" ... [et al.], 2007, 9, (3), pp. $72-78$

5. Coster, E.A., Coetsee, L.D., and van Niekerk, A.M.: 'The quality of working life of a group of dentists', The Journal of the Dental Association of South Africa = Die Tydskrif van die Tandheelkundige Vereniging van Suid-Afrika, 1979, 34, (10), pp. 563-568

6 Bergstrom, K., Soderfeldt, B., Berthelsen, H., Hjalmers, K., and Ordell, S.: 'Overall job satisfaction among dentists in Sweden and Denmark: A comparative study, measuring positive aspects of work', Acta odontologica Scandinavica, 2010, 68, (6), pp. 344-353

7. Leggat, P.A., Kedjarune, U., and Smith, D.R.: 'Occupational health problems in modern dentistry: a review', Industrial health, 2007, 45, (5), pp. 611-621

8.. Fahim, A.E.: 'Predictors of job satisfaction among practicing dentists at hospitals in Suez Canal Area, Egypt', International journal of occupational medicine and environmental health, 2013, 26, (1), pp. 49-57

9. de Ruijter, R.A., Stegenga, B., Schaub, R.M., Reneman, M.F., and Middel, B.: 'Determinants of physical and mental health complaints in dentists: a systematic review', Community dentistry and oral epidemiology, 2015, 43, (1), pp. 86-96

10. Puriene, A., Aleksejuniene, J., Petrauskiene, J., Balciuniene, I., and Janulyte, V.: 'Self-perceived mental health and job satisfaction among Lithuanian dentists', Industrial health, 2008, 46, (3), pp. 247-252

.11. Leggat, P.A., and Smith, D.R.: 'Musculoskeletal disorders selfreported by dentists in Queensland, Australia', Australian dental journal, 2006, 51, (4), pp. 324-327

12. Goldacre, M.J., Lambert, T.W., Goldacre, R., and Hoang, U.: 'Career plans and views of trainees in the Academic Clinical Fellowship Programme in England', Medical teacher, 2011, 33, (11), pp. e637-643

13. Bates, L.F., Buehler, A.M., Boynton, J.R., Majewski, R.F., and Inglehart, M.R.: 'Pediatric dentists' job satisfaction: results of a national survey', Pediatric dentistry, 2013, 35, (4), pp. 343-350 
14. Harris, R., Burnside, G., Ashcroft, A., and Grieveson, B.: 'Job satisfaction of dental practitioners before and after a change in incentives and governance: a longitudinal study', British dental journal, 2009, 207, (2), pp. E4; discussion 74-75

15. Bedi, H.S., Moon, N.J., Bhatia, V., Sidhu, G.K., and Khan, N.: 'Evaluation of Musculoskeletal Disorders in Dentists and Application of DMAIC Technique to Improve the Ergonomics at Dental Clinics and Meta-Analysis of Literature', Journal of clinical and diagnostic research : JCDR, 2015, 9, (6), pp. ZC01-03

16. Sharma, A., Sharma, V., Sharma, S., and Singh, P.: 'Awareness of biomedical waste management among health care personnel in jaipur, India', Oral health and dental management, 2013, 12, (1), pp. $32-40$

17. Dyrbye, L.N., Sotile, W., Boone, S., West, C.P., Tan, L., Satele, D., Sloan, J., Oreskovich, M., and Shanafelt, T.: 'A survey of U.S. physicians and their partners regarding the impact of workhome conflict', Journal of general internal medicine, 2014, 29, (1), pp. 155-161

18. Sotile, W.M., and Sotile, M.O.: 'Physicians' wives evaluate their marriages, their husbands, and life in medicine: results of the AMA-Alliance Medical Marriage Survey', Bulletin of the Menninger Clinic, 2004, 68, (1), pp. 39-59

.19. Roger, J.M., Wehmeyer, M.M., and Milliner, M.S.: 'Reflections on academic careers by current dental school faculty', Journal of dental education, 2008, 72, (4), pp. 448-457

20. Lowenstein, S.R., Fernandez, G., and Crane, L.A.: 'Medical school faculty discontent: prevalence and predictors of intent to leave academic careers', BMC medical education, 2007, 7, pp. 37

21. Sampasa-Kanyinga, H., Chaput, J.P., and Hamilton, H.A.: 'Associations between the use of social networking sites and unhealthy eating behaviours and excess body weight in adolescents', The British journal of nutrition, 2015, 114, (11), pp. 1941-19477

22. Shiue, I.: 'Duration of daily TV/screen watching with cardiovascular, respiratory, mental and psychiatric health: Scottish Health Survey, 2012-2013', International journal of cardiology, 2015, 186, pp. 241-246

23. Peiro-Velert, C., Valencia-Peris, A., Gonzalez, L.M., GarciaMasso, X., Serra-Ano, P., and Devis-Devis, J.: 'Screen media usage, sleep time and academic performance in adolescents: clustering a self-organizing maps analysis', PloS one, 2014, 9, (6), pp. e99478

24. Gates, M., Hanning, R.M., Martin, I.D., Gates, A., and Tsuji, L.J.: 'Body Mass Index of First Nations youth in Ontario, Canada: influence of sleep and screen time', Rural and remote health, 2013, 13, (3), pp. 2498

25. Borgan, S.M., Jassim, G., Marhoon, Z.A., Almuqamam, M.A., Ebrahim, M.A., and Soliman, P.A.: 'Prevalence of tobacco smoking among health-care physicians in Bahrain', BMC public health, 2014, 14, pp. 931
26. Jawad, M., Abass, J., Hariri, A., Rajasooriar, K.G., Salmasi, H., Millett, C., and Hamilton, F.L.: 'Waterpipe smoking: prevalence and attitudes among medical students in London', The international journal of tuberculosis and lung disease : the official journal of the International Union against Tuberculosis and Lung Disease, 2013, 17, (1), pp. 137-140

27. Dar-Odeh NS, Al-Abdalla M, Khdairi N, Al-Abedalla K, AbdelJawad RS, Abu-Hammad OA: 'Narghile (water pipe) smoking among university staff; prevalence, attitudes and beliefs', Adv Appl Sci Res, 2013, 4, (1), pp. 7

.28. Dar-Odeh NS, Abu-Hammad OA, Al-Abedalla M, Shakatreh FM, Al-Abedalla KB, Khdairi NO, Prime SS: 'Narghile smoking among Jordanian educated working women: attitudes and beliefs', British Journal of Medicine and Medical Research, 2013, 3, (3)

29. Schenkein, H.A., and Best, A.M.: 'Factors considered by new faculty in their decision to choose careers in academic dentistry', Journal of dental education, 2001, 65, (9), pp. 832-840

.30.Trower, C.A.: 'Making academic dentistry more attractive to new teacher-scholars', Journal of dental education, 2007, 71, (5), pp. 601-605

31. Kay, E.J., and O'Brien, K.D.: 'Academic dentistry--where is everybody?', British dental journal, 2006, 200, (2), pp. 73-74
Publish in International Archives of Medicine

International Archives of Medicine is an open access journal publishing articles encompassing all aspects of medical science and clinical practice. IAM is considered a megajournal with independent sections on all areas of medicine. IAM is a really international journal with authors and board members from all around the world. The journal is widely indexed and classified Q1 in category Medicine. 